\title{
LA NOVELA Y LA PROSA DEL MUNDO*
}

\author{
Claudio Magris**
}

\section{Hegel se preguntaba si en el mundo} moderno, el individuo todavía tendría algún poder para plasmar la realidad.

Si en la antigüedad el individuo podía ser soberano o bien el siervo de un soberano personal, en la edad moderna, el individuo depende de todos y todos de ninguno; es decir, de la anónima red de los enlaces y las relaciones sociales en las cuales se encuentra siendo un medio, usado por el mecanismo colectivo para fines que le son extraños y desconocidos.

El individuo que aspira a la autonomía y a la plenitud de su persona, se reduce a un rol. No puede ver a la cara a su señor, como el esclavo antiguo, porque el poder que lo domina es la totalidad impersonal del sistema social, al cual todos obedecen, también los jefes políticos y económicos, quienes son solamente funcionarios -aunque de alto nivelde aquel sistema general y objetivo que parece moverse automáticamente.

Esta estructura de relaciones es la prosa del mundo, como la llamaba Hegel. El individuo quisiera vivir aventuras irrepetibles y experiencias inconfundiblemente personales, quisiera moverse en un mundo sensible y concreto, lleno de significado, como las selvas de la antigua mitología, pobladas por los dioses, y protegido por valores capaces de rescatar el

*Del libro Itaca e altre, 1982, Garzanti. Traducción de Luz Aurora Félix.

Germanista y escritor italiano. Sus novelas El Danubio y Otro mar han sido publicadas en castellano por Anagrama. 


\section{Claudio Magris}

causal transcurrir de las cosas de la eventualidad y la indiferencia. El individuo quisiera que su vida fuera verdaderamente suya, es decir, quisiera vivir poéticamente, en cambio, se mueve en la prosa.

La novela es el género literario que nace de esta prosa del mundo y la hace propia. Don Quijote, que se obstina en recorrer las calles polvorientas y vacías de la modernidad para descubrir un encanto insustituible en cada cosa y en cada acontecimiento cotidiano, es el último caballero de la epopeya: el yelmo de Mambrino que don Quijote porta es una vasija de barbero, es uno solo, tiene un significado de por sí, en cambio las vasijas son intercambiadas.

Pero don Quijote es un loco que desconoce el curso del mundo; Hegel indica la necesidad de medirse con aquella prosa y de adecuarse a su necesidad. La novela moderna para él debe ser la historia de este individuo huérfano de los dioses pero incapaz de renunciar a la poesía de la existencia. La novela ocupa el lugar del poema épico de la tradición, que se basaba en el sentido significativo de la unidad del mundo -preservada por la trascendencia de lo divino y de los otros valores no gastados por el tiempo y por la casualidad- que transmitía de generación en generación la respiración ininteriumpida de la continuidad de la vida, 8 rica de sentido y de poesía.

Desde la época de Hegel, que tenía en mente las novelas de Goethe, la precariedad de lo individual con respecto a lo universal siempre estuvo en el centro de la problemática narrativa; adquiriendo un relieve tanto más intenso cuanto más anónimo y amenazadoramente incontrolable parecía aproximarse aquel universal, aquella totalidad general y genérica de la vida social. Todas las grandes novelas se basan en este tema, y las más verdaderas no ceden ni al fácil ni engañoso optimismo de que el individuo sea soberanamente autónomo, ni a la complacencia de darlo tranquilamente por muerto.

La grandilocuencia edificante o catastrófica no hace justicia al destino del individuo y lo abandona, aún más desvalido a la abstracción que lo amenaza. Berlin Alexanderplatz, la obra maestra de Alfred Döblin -aparecida en 1929 y ahora publicada nuevamente en la versión ya clásica de Alberto Spaini- es uno de los más bellos libros de la literatura de este siglo dedicados a la inadaptación, cuyo estilo y estructura se identifican 
con la sorda resistencia del individuo. Es la historia de Franz Biberkopf, estibador de Berlín, que al cabo de cuatro años de prisión intenta una nueva vida pero, mal encaminado, luego de perder un brazo y de que su novia, la tierna prostituta Mieze, fuera asesinada, termina en un manicomio. El narrador lo abandona cuando le es ofrecido el trabajo de portero en una fábrica, en un final abierto -como lo es toda la novelaa la inmensa y seductora vida metropolitana.

Franz Biberkopf se halla en esta realidad vertiginosa e indiferente: su existencia y vicisitudes, entrelazadas, son un montaje de variados fragmentos que constituyen el hormigueo de la modernidad. Berlín, la metrópoli caótica e impersonal lleva al extremo la prosa del mundo, el abstracto y anónimo engranaje que coordina, sintoniza y tritura la vida de los hombres. Las plazas, las calles, los anuncios luminosos, la circulación de los tranvías, la ola del tráfico, el eco de las canciones populares, los olores de las cervecerías, el babélico parloteo colectivo del dialecto berlinés, se cruzan, entrelazan y se disuelven en la persona de Franz y en su odisea. Sólo Joyce ha revelado con semejante fuerza poética el inmenso sedimento colectivo que se encuentra bajo el gesto de todo individuo. Como en las novelas de Dos Passos su Nueva York, también en Berlin Alexanderplatz es el ritmo plural de la metrópoli que teje y deshace, como un agitado caleidoscopio las figuras y los destinos. Mientras que en Dos Passos el individuo es solamente pasivo, una mera cristalización provisoria de las relaciones sociales, Döblin no sólo expresa la pasividad de su héroe en el desencanto del mundo, sino también su resistencia -ardua y obtusa, pero impávida y maliciosa- a aquel desencanto.

Construida según la técnica del montaje, la novela muestra cómo también un individuo es en gran parte un collage heterogéneo y discontinuo, cómo en el corazón de este individuo que se levanta después de cada knock out que le da el mundo, no se apaga una sacralidad bíblica, que lo mantiene en la continuidad épica de la vida.

Otro gran intérprete y diagnosticador de la irrealidad contemporánea, Herman Broch, ha escudriñado magistralmente -en su novela en once cuentos Los inocentes - la seducción que la objetiva abstracción de la vida ejerce sobre el individuo persuadiéndolo de dejarse llevar por la propia 


\section{Claudio Magris}

falta de autoridad a declinar toda responsabilidad. Heredero de la tradición augsburga y hebrea, poeta de formación matemática y de inspiración religiosa, Broch analiza en sus obras el eclipse de un valor central que diese un sentido a la vida y sobre el cual se podría fundar una civilización. Retrata el sonambulismo del individuo contemporáneo que se mueve espectral y alienado en relaciones cada vez más vacías y abstractas, defraudado de toda realidad concreta y significativa, gobernado por una racionalizacion formal que oculta bajo su impecable simetría protocolar, el abismo de lo irracional.

En una gama de situaciones y parábolas diversas pero ligadas, que abraza la existencia privada y grandes eventos políticos como el nazismo, Los inocentes muestra individuos sin nombre y sin rostro, que se mueven en la perfecta geometría de las estructuras del mundo, separados de la cálida, oscura e inexplicable vida real que parece disuelta, y fascinados por aquel inocente y culpable juego con las formas que los aliena y los anula. El individuo que cede ante esta seducción de la inercia y de lo abstracto pierde vitalidad, amor, la fuerza de crecer y madurar, de amar y generar amor; de tal demoníaca irrealidad, nace también el nazismo, supremo triunfo del evadirse de la vida. Sin sustraerse a la debilidad del

10 individuo, Broch muestra que su deber es rechazar la prosa del mundo, de mandar la débil pero indestructible exigencia de absoluto que hay en él, un absoluto que trasciende la totalidad social.

- Ernst Jünger, al contrario, cree en la enorme fuerza del individuo, como escribe en su última novela Eumeswil. Contando actualmente ochenta y seis años (nació en 1895), ${ }^{*}$ Jünger es tal vez uno de los últimos representantes de la generación que ha vivido y teorizado el vitalismo y el nihilismo de principios de siglo. En sus implacables Diarios de guerra, él ha descrito con lúcida transparencia y patética fascinación por la sangre, el arrebato del impulso vital sustraído a todo juicio moral, los eventos -aun destructivos-que suceden simplemente porque suceden, privados de sentido y valores, como la mano que dispara y mata. Más tarde, convertido en el frágil e inhumano ideólogo de la vitalidad imperturbable por las ideas, ha predicado por aquel puro gesto vital que -él

\footnotetext{
${ }^{*}$ Escrito en 1981 (n.t.).
} 


\section{LA NOVELA Y LA PROSA}

sabía bien- pudo ser sencillamente ejecutado y observado, mas no teorizado.

Si bien cercano al nazismo, Jünger se aparta de éste en nombre de un ethos militar aristócrata, altivo ante la vulgaridad, y también por una aversión estético-moral a la tiranía hitleriana. Su proximidad al nazismo -causa de un ostracismo injusto hacia su honestidad intelectual- ahora que la cultura de izquerda busca a sus maestros en los anárquicos de derecha con su radicalismo antiburgués, tiende a hacerle un ambiguo favor. El individuo anhelado por Jünger es el "anarco", que permanece íntimamente separado de todo aquello que lo circunda, participando en cualquier realidad social pero sin involucrarse con ella. Anarco es el protagonista de Eumeswil, Martin Venator, histórico y steward en la corte de un tirano, el Cóndor, que reina sobre una ciudad de ciencia ficción que sobrevivió al fin del mundo, en un futuro tecnológicamente avanzado y decadente, como un resto arcaico, entre cielos fantásticos y refinamientos feudales.

Jünger quisiera restaurar el mito y entrelaza futurismo y residuos, confiando en que la técnica pueda infundir una nueva belleza heráldica al mundo. Pero él olvida que el individuo no se contrapone al Leviatán, como San Jorge al dragón, pero debe combatirlo antes que nada en sí mismo, erradicando de esa parte de sí que ya es leviatán, masa despersonalizada y vacía abstracción. Sin esta consciencia la lucha del individuo es irreal como un torneo; la novela con su elegancia seca y punzante pero dispersa, se esfuma como las agujas de un castillo bellísimo, pero falso. Aquella elegancia no basta para traer de nuevo a los dioses -si existen todavía escondidos en alguna parte- es más fácil encontrarlos en la humilde ciudadanía descrita por Broch o en un tranvía repleto de gente de la Alexaderplatz berlinesa.

\section{Flaubert y el libro sobre la nada}

Kafka soñaba a menudo que se encontraba en una sala grande llena de gente y desde el podium leía en voz alta, íntegra y sin interrupciones $L a$ educación sentimental. 


\section{Claudio Magris}

Era una fantasía de poder, el deseo de dominar a los demás con la única arma que le proporcionaba una superioridad a su altura, es decir, con la palabra. Pero a las veleidades del poder entrelaza, nostálgico y ambiguo, el amor: para fascinar a los oyentes y para mantenerse -enmedio del tumulto de la vida real y de esa imaginaria sala repleta-Kafka se imagina aferrado a ese enorme libro de amor, a un libro de todo encanto y de toda desilusión. En sus cartas y en sus diarios el nombre de Flaubert aparece con frecuencia y con pasión, referido especialmente hacia $L a$ educación sentimental, obra maestra de un escritor al que quizás amaba más que a ninguno, en el que descubría al mismo tiempo al fundador y al culminador de aquella literatura moderna de la soledad y de la carencia a la que él mismo se sentía perteneciente; un padre pero también un hermano, a la vez huérfano y solo, hacia el cual no se experimenta el infantil y necesario impulso filial de la rebelión.

Kafka pensaba en La educación sentimental cuando soñaba que seducía a su hipotético auditorio, porque advertía la gracia indecible e inexorable que recorre sus páginas, su pura e inmaterial forma musical. Flaubert aspiraba a escribir, como decía en 1852 a Louise Colet, preciosa confidente literaria y amante demasiado imprudente, "un libro sobre la nada", "un libro sin apoyos exteriores, que se sostuviera solamente por la fuerza intrínseca del estilo, como la tierra se mantiene en el aire sin necesidad de sostén; un libro casi sin sujeto, o al menos cuyo sujeto fuera, si fuese posible, casi invisible".

La indignación de los austeros moralistas y el aplauso de los charlatanes estetas, igualmente han malentendido a Flaubert y su dedicación a la forma. La revelación poética, que ciñe la mente y toca el corazón, haciendo aparecer de improviso la verdad de la vida, es siempre una forma, un ritmo que hace percibir el fluir de la existencia. Si la música es la experiencia más elevada de la intensidad de la vida, contenida toda en el estilo, podríamos decir entonces que el jovencito que lee Los tres mosqueteros, y que más tarde, como adulto recuerda esa obra, se siente arrebatado no tanto por el tema -por una intriga determinada o por la escena de un duelo por ejemplo- sino más bien por el flujo del relato que lo conduce y ora le pone freno, ora le da rienda suelta... Flaubert es un maestro, sobre todo en La educación sentimental, de ese encanto, que 
no nace de aquello que acontece sino de la melodía de los acontecimientos, de la forma que les da una unidad y un sentido -también cuando expresa, como en esta novela, el indefinido diluirse de la vida- y hace indeleble e incomparable cada detalle único, en sí mismo insignificante. No obstante su mediocre pronunciación francesa, Kafka ambicionaba poner su voz al servicio del estilo de Flaubert porque sabía que era el ritmo de aquella prosa, es decir aquel respiro épico, el que daba realidad a los personajes y a sus pasiones: a la mirada de Madame Arnoux, inextinguible perdición amorosa; a un gesto de Rosanette, la tierna y generosa fugacidad sentimental; como la conversación de un salón aristocrático o el movimiento de una calle parisina mostraba la historia de Francia y de Europa en esos años cruciales alrededor del '48, cuya agitación condiciona y determina aún nuestro mundo actual.

Amargo y burlón profeta de un futuro imbécil, Flaubert lo veía nacer desde su presente y advertía la tendencia general de la civilización moderna a vaciarse de toda sustancia para reducirse -desde el arte hasta la ciencia o la política - a un falso formalismo, que degradaba el ideal de la forma -ascética, pero vibrante de vida y de nostalgia de la vida-a mera corrección formal del pensamiento, del discurso y de la organización social. El sujeto inexistente o casi invisible del proyectado libro sobre la nada es también el vacío estridente de charlas sobre el cual han sido construidas la civilización y la sociedad, la nada sobre la que se lanzan y vuelven las palabras y las creencias, los insolentes programas y los triunfos imaginarios; es el suelo ausente sobre el que se fundan las ciudades, los estados y las iglesias, las verdades y las filosofías; es esa inexistencia de un fundamento la que transforma toda la realidad en una de esas Corporaciones Públicas que sobreviven a los designios por los que fueron instituidas y continúan funcionando perfectamente y sin meta.

De este nihilismo, pomposamente alimentado por esperanzas y promesas, Flaubert ha sido el crítico implacable y preciso. Pero Flaubert ha vuelto su burla también hacia sí mismo, a su propio apasionamiento elocuente y romántico, para dar a su sentimiento la verdad de la distancia y salvarlo de la falsedad de la inmediatez declamatoria. De la autobiografía de Carême, el gran cocinero de Talleyrand había aprendido que 
Claudio Magris

el arte de la cocina y su asidua práctica lo habían corregido de una excesiva inclinación a la glotonería. El estilo, al cual Flaubert sacrifica la propia existencia no persigue los pretensiosos y autosuficientes artificios lingüísticos, celebrados por los literatos de vanguardia con una alborozada presunción semejante al torpe entusiasmo de Bouvard y Pécuchet, por la química, la mitología céltica y el espiritismo.

El estilo es una manera absoluta de ver las cosas en su esencia, es el modo de reencontrar la vida, su sentido desgarrador y secreto que destella sólo más allá de las efusiones sentimentales, de las acrobacias intelectuales y de los adornos estetizantes. Este estilo es fruto de una inimaginable fatiga y padecimiento, de un rigor que obedece a la sentencia evangélica, según la cual sólo quien esté dispuesto a perder la propia vida, la salvará. Normando sanguíneo, amante de grandes placeres y poco inclinado al sacrificio, Flaubert intuye la variante abierta a la modernidad entre la existencia y el significado que debería iluminarla, entre vivir y escribir, pero es la nostalgia por la vida verdadera y no vivida la que lo induce a la escritura. El sujeto imperceptible del libro es la vida verdadera en su transcurrir y disiparse, que se mantiene por sí misma porque en ella tiene la flama de su fluir, su sentido inexplicable y huidizo,

14 inapresable por ninguna imagen, que la envuelve en un aura vibrante de voces y ecos para arrastrarla consigo, lejos.

El sujeto invisible es el transcurrir del tiempo, su hebra que se desenvuelve en los minutos, las horas, los años. La educación sentimental, aparecida en 1869 -de la cual Flaubert había escrito una primera versión en 1845 , muy distinta y centrada en el contraste entre realismo y lirismoes la novela del tiempo, que forma y destruye la individualidad, y del amor, el doloroso antagonista de Cronos.

Es la historia del joven Frédéric Moreau, de sus intentos de ascender en la escala social, de sus ilusiones y desilusiones, que son las de toda su generación, completamente fracasada en todos los aspectos -sentimental, intelectual y político- y fatalmente dirigida por la obtusa anarquía de Julio a la trágica farsa del Cuarenta y ocho (al menos así piensa Flaubert), a la corrupción del Segundo Imperio y a la catástrofe de 1870-1. La novela es la historia de la pasión de Frédéric por Madame Arnoux, nunca saciada y nunca apagada; tema dificilísimo y desarrollado con maestría 
absoluta: rostro universal del amor posible, vislumbrado y soñado, pero no vivido.

El tiempo que une y separa casualmente a los hombres conduciéndolos al encuentro con la felicidad, en el momento equivocado hace absurdo e incoherente cada suceso, pero Flaubert -anotaba el joven Lukácsha cumplido el milagro de dar sentido a la insensatez de la vida, de evocar todo aquello que ella quita luego de haberlo prometido, de narrar la odisea de los hombres modernos expulsados del paraíso terrenal -de una tierra de valores duraderos-y abandonados a la fugacidad.

Ciertamente no se puede leer La educación sentimental sin interrupción, como fantaseaba Kafka, porque en el libro, observaba Proust, cuenta también aquello que es callado, los espacios blancos y los intervalos vacíos que se desvanecen entre un capítulo y otro, el tiempo perdido y muerto transcurre en vano entre la trama de la historia.

Tal vez ni siquiera Proust ha imaginado con igual intensidad el transcurrir del tiempo, que teje la vida y el amor; o al menos Flaubert, que en las noches de su obsesivo trabajo ha pagado a la escritura un precio no menos alto que el de Proust, ha disimulado mejor tal esfuerzo, lo ha resuelto y disuelto en la representación de la encantadora simplicidad de la existencia, cuyo rostro más bello y delicado es tal vez el de Rosanette, la cortesana apasionada y voluble, tierna y maternal, superficial y generosa, adorable cuando baila en las fiestas galantes, y también cuando, envejecida y gorda, adopta un niño.

Rechazando la imposición de una estructura arquitéctonica y dominante, Flaubert con la novela persigue captar la inquietud del devenir en todas sus formas, desde los amores en los carruajes públicos a los grandes acontecimientos históricos. No se puede resumir la novela, sería necesario citarla completamente, copiarla como hacen ciertos personajes de Borges con las obras maestras del pasado, o Bouvard y Pécuchet con sus documentos. Flaubert ha enseñado a los modernos la poesía de lo accidental y de lo fortuito, pero con una impasible sutileza, lección que ha sido repetida por muchos grandes maestros posteriores: por ejemplo Joyce, cuando se concentra en el más mínimo detalle, o Thomas Mann, cuando opone la vida y el espíritu, revelan una ingenua reiteración didáctica. 
Claudio Magris

El tiempo de La educación sentimental es también un tiempo histórico, la época anterior y posterior al ' 48 , que Flaubert recoge en toda la profundidad y variedad de sus elementos políticos y sociales, sin los cuales toda poesía permanece abstracta. Flaubert describe con igual aspereza la cruel imbecilidad conservadora y la confusa imbecilidad revolucionaria, en aquel capítulo hilarante y trágico sobre ese momento histórico, que constituye la cima de su arte y continúa siendo actual con respecto al torrente de palabras vacías que inundan nuestros pequeños y recurrentes "cuarenta y ochos" y "segundos imperios", donde también "existieron hombres de ingenio que se volvieron cretinos de golpe y para toda la vida". Sin embargo, Flaubert se incluye también a sí mismo en la imbecilidad fatal de lo real, así como inserta algunas de sus palabras e ideas en el "estupidario" de ideas y frases hechas cultivadas por Bouvard y Pécuchet.

La existencia entera es un lugar común y Flaubert nos hace sonrojar cuando hablamos de política, del misterio del universo, de la represión, de la crisis de los valores o del hombre. Pero su ferocidad desmitificadora es acompañada por una gran ternura para quien, a través de los lugares comunes -y no sería posible de otra manera- busca su propio camino y

16 dice torpemente la verdad de sus afanes. Los diálogos pasionales de Madame Bovary nos enseñan que no hay amor sin mentira ni soliloquio vanidoso, pero en esa retórica habla también la auténtica nostalgia de la felicidad, el dolor del alma. No hay amor sin ironía, peor, no hay ironía sin amor: Bouvard y Pécuchet son ridículos pero heroicos, Monsieur Arnoux es vulgar y banal, pero su trivial iniciativa cotidiana no está privada de una grandeza simple. Flaubert es un autor que también sabe hacer reír, y para ello es necesaria una mirada desencantada, pero también una bondad superior y desbordante.

Poco después de publicar La educación sentimental, Flaubert al releer a Goethe exclama: "He aquí un hombre, pero él lo tenía todo, todo para sí." Flaubert no tenía nada, ni siquiera a sí mismo, al sentimiento compacto de la posesión de sí; estaba sólo, mirándose al espejo se soltaba a reír y sentía escaparse la indecible vanidad de la vida en un enigma indescifrable: "Je suis mystique et je ne crois à rien." Nuestra verdad no es aquella de Goethe que tenía todo, sino aquella de Flaubert, que no 
tiene nada. Si después de La educación sentimental no se hubieran escrito otras novelas, habríamos perdido grandes obras de arte, sin embargo nuestro conocimiento de la vida no sería muy diferente. Frédéric Moreau es ya nuestro yo anónimo, el hombre sin cualidades especiales, capaz de amor pero también de indiferencia e insensibilidad. Amamos a Madame Arnoux y a Rosanette, pero no amamos ni hacemos caso a Frédéric Moreau, como tampoco sentimos simpatía e interés por nosotros mismos.

Acabada la guerra y la revolución de 1870-1, frente a las Tullerías, destruidas, Flaubert decía que todo aquello no habría ocurrido si se hubiese comprendido La educación sentimental. Flaubert sobrevaloraba al entendimiento, que no es suficiente para impedir los desastres; pero frente a las peligrosas tullerías de la propia existencia, cada uno se detiene delante de la imagen de lo posible, de lo distinto, del más allá, del rostro eventual de aquel tiempo perdido entre las fallas de los acontecimientos: y su vida le parece recogerse en torno a ese tiempo perdido e ignorado, como para Frédéric Moreau la vida se condensa en torno a aquel ramo de flores que él, jovencísimo, dejara tras apenas entrar en el burdel, de donde, por timidez súbitamente huyó.

\section{El diccionario universal de Musil}

En su primera novela, Las tribulaciones del joven Törless (1906) Musil escribe que la gente adulta e inteligente se ha encerrado en una red dentro de la cual "una sostiene a la otra, de tal manera que el conjunto se ve muy natural, pero nadie sabe donde se encuentra la primera red que sostiene todo". Musil tiene veintiséis años y sobre sus espaldas una insoportable situación familiar (la convivencia del padre, la madre y su amante bajo el mismo techo), colegios y academias militares, el diploma en ingeniería mecánica del Politécnico de Brüm y la reciente asistencia al de Sttutgart, además los estudios filosóficos con Carl Stumpf -el maestro Husserl- en la Universidad de Berlín, el amor por una actriz, y luego por una muchacha del pueblo: las ambigüedades sentimentales han agudizado su sensibilidad y su nostalgia por la totalidad de la pasión. 
Claudio Magris

Musil ha leído sobre todo a Nietzsche y a Mach, sobre quien escribirá su tesis de doctorado en 1908, además a los principales escritores alemanes y europeos, y desde hace un año trabaja en el cambiante y seductor proyecto de una novela -grandiosa, sutil y tal vez interminable-con la que ambiciona representar la realidad contemporánea en su disgregación infinita, que será El hombre sin atributos, libro de toda una vida, que quedará inconcluso al momento de su muerte en 1942. Su historia también estará reflejada en los interminables Diarios que acompañan toda su existencia.

Törless, alumno de un colegio militar, pide en vano a su profesor de matemáticas que le explique la paradoja de los números imaginarios: El signo $i$ que indica la raíz de -1 , corresponde a un número inexistente (porque ningún número elevado al cuadrado da como resultado -1), pero gracias a este número, que no existe, se resuelven cálculos útiles para fines prácticos -como si se atraversara un río pasando por un puente que no existe, escribirá Musil. La ciencia, se dice en Törless, construye edificios grandiosos y compactos, pero cuando se intenta tocar sus ladrillos, éstos se esfuman en el aire. "Es la ciencia, sobre todo la matemática, que desenmascara el nihilismo del saber moderno, descu-

18 briendo que el edificio entero - del pensamiento, pero también de la misma realidad- ha saltado por los aires."

Desde sus inicios Musil -que sabe fundir como ningún otro poeta alma y exactitud, extrema tensión y rigor analítico- retrae e indaga la vida contemporánea, que ya no tiene fundamento, un humus en el cual radicarse. "La vida no vive más en la totalidad", en un todo orgánico y concluido -escribe en los Diarios, citando a Nietzsche- ya no tiene un centro de valores; es un cerco que circunscribe un vacío, como el anillo que Clarisse se quita del dedo en El hombre sin atributos.

También la trama principal de la novela La acción paralela transcurre en torno a un vacío, está construida sobre la nada. La acción paralela es la búsqueda de una idea central que pueda ser destacada como fundamento de la civilización austríaca - a manera de símbolo de toda la civilización occidental- pero dicha idea no es encontrada. Mas la sucesión de hechos de la novela es también la historia de los intentos por encontrarla y de disimular su imposibilidad, la irónica parábola de un 
mundo -el nuestro- verbosamente ocupado en problemas inexistentes, enredado en acciones que se dicen paralelas, pero sin que se sepa a qué cosa éstas pertenecen.

El héroe musiliano, el hombre sin cualidades, es un conjunto de cualidades sin el hombre, sin un centro que las unifique. Su modelo es el austríaco porque éste, dice Musil, es un austro-húngaro sin lo húngaro, que no coincide con ninguna de las nacionalidades del imperio de los Augsburgo, pero es el vínculo que las une y distingue, y por lo tanto el resultado no de una identidad definida, sino de una sustracción que lo diferencia de cada uno y hasta de sí mismo.

La Austria de Musil, dirá él mismo, será un "experimento del mundo" que revela con la evidencia de un modelo de laboratorio la multiplicidad heterogénea y contradictoria de lo real, que no se deja reducir a una determinada unidad. Por ello Austria es inexpresable, privada de nombre y de esencia, de sustancialidad, como lo son el hombre sin cualidades, la misma realidad, y también el sujeto individual, privado de ordenar las cosas porque está resquebrajado en su unidad. "El yo pierde el sentido que ha tenido hasta ahora, de un soberano que ejecuta actos de gobierno" -escribe Musil.

El hombre sin atributos es el gran libro, sutil y preciso, que representa a la realidad que ya no existe como un Todo ordenado, sino que, incontenible por el secular concepto de límite y de prohibición de lo ilimitado, se expande en todas direcciones como la propia novela que las contiene. La obra maestra de Musil es la enciclopedia, la summa total de una realidad que ya no puede ser abrazada por entero ni vivida épicamente en su espontáneo fluir, dado que ella consiste en la reflexión sobre sí misma y sobre la propia no representación. Si las grandes obras épicas dan la ilusión de la vida que se narra por sí misma, El hombre sin atributos es la epopeya de la reflexión, de la vida que indaga y retrae la propia imposibilidad de ser narrada en una historia.

La novela musiliana en subjuntivo niega el épico indicativo, aquello que es y sucede para dirigirse a las "intenciones de Dios aún no precisadas", al "sentido de la posibilidad", a las alternativas de la realidad, con el deseo de narrar aquello que podría ser y acontecer. La grandeza de Musil consiste en la extraordinaria poesía con que penetra en el meca- 


\section{Claudio Magris}

nismo de la vida, aparentemente dominado por una lógica meramente probabilística; en su capacidad de hacer brillar el sentido de la vida mientras parece que sólo analiza desapasionadamente los procesos y funcionamiento impersonal del acontecer, su combinación química. La vida no se puede narrar porque ya no se puede colocar desde aquella distancia media y convencional que permitía encuadrarla en una perspectiva armoniosa, pero ella es iluminada por esta poesía que la penetra por todas partes y la mira desde todas las perspectivas, desde una distancia cero, como desde una lejanía sideral, llegando hasta el "fluido meollo ardiente de la creación", al núcleo desde donde parte su expansión.

La perspectiva de Musil tiene trescientos sesenta grados y abarca la gama entera de lo real, como un diccionario universal que incluye todas las voces del mundo y toda inteligencia, desde el principio de razón suficiente al gran amor vagabundo, desde el capitalismo a la nieve, desde una media femenina que se deshilacha en una pierna, a las mejillas de Agathe que arden como rosas en la sombra. Musil sabe mirar al mundo con los ojos apagadamente melancólicos de su Leo Fischel, como con los amablemente estúpidos del conde Leinsdorf o los alucinados de Clarisse.

En el Secretariado General del alma y de la exactitud que Musil imagina, no existen por tanto sólo el vacío o el fragmento. En Viaje al paraíso, el capítulo de la novela que narra la unión extática de los dos amantes en un espacio absoluto entre el cielo y el mar, la belleza de Agathe es comparada a una curva que puede ser bella si se conoce el círculo que la trasciende y contiene, la totalidad de la cual ella es parte. "Si detrás de este infinito" de cielo y mar no hay nada, si eso "es inexorablemente abierto", aquel infinito es una herida, una punzada dolorosa que consume también al amor.

Musil no desiste en la búsqueda del sentido y de la totalidad de "aquel pedazo, pequeñísimo tal vez, que cierra el círculo fragmentado", de aquella unidad inasible de la vida que huye al concepto. No se hace ilusiones de que la filosofía pueda encontrar el primer nudo porque Nietzsche le ha enseñado que la red del pensamiento sofoca a la existencia; él mismo escribe: "los filósofos son violentos que no disponen de un ejército y por ello se adueñan del mundo encerrándolo en un 


\section{LA NOVELA Y LA PROSA}

sistema." Contra la rigidez dogmática, Musil quiere volver a encontrar aquel murmullo de la vida que no se deja narrar por frases bien ordenadas y con el punto final; aquella anárquica y desvinculada multiplicidad de átomos individuales del existir que reclaman una autonomía salvaje. Bajando a través de los "descosidos de los signos", bajo el bosquejo de las palabras, en la trastornada psiquis de Clarisse y de Moosbrugger, los dos casos extremos de lo humano y del dolor, Musil quiere hacer hablar a aquel fluir de lo profundo que la lógica discursiva aprisiona en la representación condenándolo al silencio, quiere dar voz a la alteridad radical, a la locura, a la división original, a todo aquello que la ratio ha reprimido y dominado, ya que ella "mide, pesa, acumula, divide como un viejo banquero".

Esta aventura lo lleva casi más allá del hombre histórico tradicional, a las orillas del "mar al sexto día de la creación, cuando Dios y el mundo estaban solos, sin los hombres". La odisea de sus personajes "nihilistas y activistas" es rectilínea, sin fin y sin regreso a casa; Musil es el poeta del individuo que se transforma radicalmente, que se convierte en otro, que cambia su ser, como el superhombre imaginado por Nietzsche. El hombre sin atributos es la odisea de nuestro presente, el retrato de aquellas individualidades que reclaman una exasperada autonomía, y con ella el fin de toda jerarquía, pero también de toda relación con los demás y con su misma persona: "Todo nuestro ser no es más que un delirio de muchos" y "la más profunda asociación del hombre con sus semejantes es la separación" -escribe Musil. Esta despiadada infinidad rectilínea no deja nada atrás. Musil ignora la procreación y la descendencia, la continuidaci y la repetición edípica. Mientras que el Ulises de Joyce es el poema épico circular, paterno y materno, que salva y hereda con fidelidad conservadora la continuidad de un orden, la obra de Musil describe el desmoronamiento de ese orden milenario.

Si Aghate no es una curva, sino más bien el fragmento de una curvatura indecisa en el infinito, el amor no se rinde en esta fragmentación pero busca y persigue el sentido oculto en el infinito, la gran unidad de la vida. Musil no la encuentra, pero no cesa de expresar nostalgia de ella, y ésta es su poesía. La ironía agudiza el encanto, la cortedad de miras enseña a sonreir de la propia estupidez, reconociéndola como destino general 
Claudio Magris

de la época. La poesía, diría Nietzsche, es el don de continuar soñando sabiendo que se esta soñando.

\section{Je ne commence pas}

Quelque chose pour commencer, monsieur?, preguntaba el mesero al cliente absorto y silencioso sentado a la mesita del pequeño restaurante parisino que no se decidía a tomar nada, ni siquiera un aperitivo. Je ne commence pas, respondió finalmente el señor, alisándose los bigotes amarillentos por la nicotina. "Yo no tengo nada para empezar, estoy acabado."

En su irónica y casi complacida desesperación, Joseph Roth no se equivocaba, presa de un colapso poco tiempo después, mientras conversaba con los amigos, en su acostumbrada mesa del café Tournon, sería transportado al hospital Necker, el hospital de los pobres, donde moriría a los pocos días, el 27 de mayo de 1939 a las 5:45 de la mañana.

$\mathrm{El}$ informe médico indicaba como causa de la muerte una pulmonía, debida a una ligera afección bronquial que degeneró en las últimas horas,

22 durante su breve estancia en el hospital. Atado con correas al lecho del miserable hospital, Roth había sucumbido a las comvulsiones del delirum tremens, agravadas por la repentina falta de alcohol que los médicos despiadadamente le infligían al buen bebedor, con lo que aumentaban sus sufrimientos y apresuraban su agonía.

Roth, mientras subía vacilante y sostenido por sus amigos a la ambulancia que debía ilevarlo al hospital había dicho sus últimas palabras; luego de poner fatigosamente el pie sobre el estribo, se había apartado con trémula pero intrépida galantería para ceder el paso a Madame Alazard, la fiel propietaria del café Tournon y a Friederike Zweig, la ex mujer de Stefan Zweig, que lo acompañaba al hospital: "Primero las damas".

El certificado de defunción emitido por el hospital no mencionaba su actividad literaria y, más aún, lo definía como un individuo sin profesión. Ciertamente esta calificación le habría gustado, ya que en los últimos meses de su autodestrucción, durante los cuales escribiera con una 


\section{LA NOVELA Y LA PROSA}

mágica e irreal lucidez algunos de sus más grandes cuentos, Joseph Roth se había obstinado en proclamar la vanidad de la literatura, es decir de su único trabajo posible. También le habría gustado la errónea indicación de su lugar de nacimiento, que no correspondía sino a una de sus muchas ficciones con las cuales él, lanzado en una interminable fuga con la que constantemente se despojaba de su identidad y de su pasado, mistificando y falseando su vida, la reinventaba sin cesar para así salvarla de la destrucción, en una narración excesiva y sobrecogedora. Una biografía de Roth -como la exhaustiva y voluminosa recientemente escrita por David Bronsen-debe tomar en cuenta las noticias imaginarias y contradictoras que Roth ha difundido por su propia cuenta. Su verdadera biografía es esta mistificación con la cual el juglar del atardecer de la vieja Europa y de la misma identidad individual ha enmascarado su propia odisea.

Los antiguos exhortaban a desconfiar de los poetas que dicen muchas mentiras, pero sabían que estas mentiras eran la verdad del destino de los poetas y de los hombres, la secreta verdad de sus sueños, de sus dolores y del juego con el cual se trata de entretener al dolor. Roth sabía que el poeta y el individuo modernos para sustraerse al inagotable tema del anonimato y del poder, tienen que enajenarse en un juego más sutil y difícil que el de los antiguos; tienen que saber disimular y transformarse como los héroes de las metamorfosis, incompatibles con toda forma rígida definitiva, y tienen que convertirse en malabaristas y equilibristas, siempre en equilibrio en el hilo de la ficción.

Intérprete y autor de la propia leyenda, Roth confunde su origen y, hasta que la suerte se lo consiente, su fin. Confía diversas indiscreciones sobre su propio nacimiento e inventa distintas versiones de la misteriosa figura paterna; asimismo modifica la nacionalidad de la madre en distintas variantes y refiere en grados variables su ascendencia hebrea. Transforma los galones de cabo austro-húngaro durante la Primera Guerra Mundial en charreteras de oficial. Habiendo sido socialista y anarquista en su juventud, en los últimos años y sobre todo en el exilio parisino, se convierte en legitimista ausburgo; actúa con convicción apasionada en el papel del monárquico y en el católico, sin renegar de su hebraísmo, y entre los distintos amigos defiende confidencias discrepantes acerca de 
Claudio Magris

su conversión al catolicismo y su fidelidad al judaísmo. También el juego en este caso es la máscara de la verdad; en las últimas obras de Roth un universalismo católico, imperial y tiernamente comprensivo de la errónea fugacidad sensorial se coloca fraternalmente junto al sentido hebreo de la vida, entendida como exilio y espera mesiánica, identificada con el llamado de una negación a la que resiste tenazmente.

Sin embargo, la mistificación es también el disimulado juego con la nada, que disuelve aquellas figuras de una esperanza (hebrea o católica), amada pero ilusoria. Póstumo director de sí mismo, Roth casi parece haber inspirado también su grotesco y conmovedor funeral: el embarazo y malhumor entre los amigos, indecisos entre celebrar el rito católico o el hebreo; la solidaridad de tres mujeres amadas (la actriz Sybil Rares, nacida en Bucovina, la lituana Sonja Rosenblum y la mulata Manga Bell, compañera de los últimos años) unidas en la tristeza de su muerte; la pálida corona depositada en nombre de su majestad Otto de Ausburgo, el monarca austríaco en exilio y nunca coronado; el ramo de claveles rojos lanzado a la fosa por el compañero Egon Erwin Kisch, jefe de la Guardia Roja vienesa, también en nombre de los otros comunistas y socialistas; y la guirnalda roja-blanca-roja de la "Liga por Austria espiritual" -de

24 aquella Austria cuya idea universal, como se ha dicho, había sido descubierta o inventada cuando el Estado que habría tenido que encarnarla ya no existía.

Joseph Roth no había tenido aquella benigna muerte que le tocara al santo bebedor de su narración y que había deseado. Lanzado con altiva indolencia al amanecer, había vivido sus últimos momentos en una febril agitación, aunque contenida por un burlón estilo aristocrático. A los cuarenta y cinco años (había nacido el 2 de septiembre de 1894 en Volinia) estaba física y moralmente destruido. Sus rasgos muestran un rostro envejecido y sudoroso, los ojos llorosos -semicerrados por temor a la luz, como si estuviera somnoliento- en cuyo fondo, sin embargo, se anida una mirada que sarcásticamente sitúa la nada, el peso de las espaldas agobiadas.

Realmente la vida había terminado para Roth. Él había sido el poeta del final. En su obra y en su existencia el final tenía muchos rostros, que sin embargo son variantes de una única descomposición: la disolución 


\section{LA NOVELA Y LA PROSA}

del imperio de los Augsburgo vivida como despedida de la totalidad y la coralidad épica; la insensata tormenta de la historia que arrastra al individuo de Oriente hasta Occidente y viceversa, en la vana búsqueda de una patria; la transformación tecnológica del totalitarismo moderno que culmina en el nazismo y que prosigue con sus victorias por toda Europa.

Roth puede terminar como el último de los Trota, que al alba, mientras las tropas nazis entran en Viena, después de haber saludado la cripta de sus emperadores no sabe adónde ir; o bien como el "superfluo" Franz Tunda de la Fuga sin fin, que la novela abandona apático y aturdido en el fluir del tráfico en una plaza parisina; o también como el mercader de corales, el judío Nissen Piczenik, que sueña con la quietud del fondo del mar.

El amanecer de Roth es a la vez una nostalgia del fin y una lucha contra esta nostalgia. En París, único refugio de la Europa aún libre del fascismo, Roth vive la existencia del errante cuya casa es el hotel o el café, últimas imágenes acogedoras de un mundo que ya no conoce intimidad. Egocéntrico y generoso, vive de deudas, mantenidas con arrogancia, prodigándose en una incansable ayuda a innumerables víctimas de la tragedia histórica, que él asiste con la decisión de quien ha comprendido que la mano tendida al que sufre vale más que la dedicada a escribir. Imagina impracticables proyectos políticos para combatir al nazismo, y asaltado por la paronoia se nutre de alcohol, que apenas le permite comer una galleta al día. Sabe que el Pernod le quita años de vida, pero los sacrifica a las semanas o meses que el licor le deja vivir.

Fascinado por la muerte, Roth se prohibe esta fascinación y predica el deber humano y religioso de vivir para servir a los demás y para luchar contra el nazismo. Establece un juicio apocalíptico acerca de toda la historia moderna, injusta y pueril en su maníaca condena absoluta, pero clarividente con ciertas agudas intuiciones. Él mismo se convierte en víctima universal de este juicio, viviéndolo en su persona hasta disgregarse, pero logrando fijarlo en la transparente magia de sus parábolas, mucho más grandes que sus novelas, a veces directas o indulgentes en el pathos. Como él había dicho de su padre, también era su especialidad la melancolía capaz de impredecible humour, como la del payaso, y de 
Claudio Magris

desdeñosa señoría. Sabía que moría, pero también sabía con certeza obsesiva que Hitler y el Leviatán serían derrotados.

Roth es el equilibrista que al final cae de la cuerda sobre la cual se mantenía, pero cae con temerario estilo. Pocos meses después de morir, su esposa Friedl hospitalizada desde hacía tiempo en un manicomio era asesinada por los nazis con los otros enfermos. "Ya nada puede infundir terror", había dicho Roth, para agregar, "en esto consiste justamente el verdadero horror".

\section{Borges o la revelación que no llega}

Si el mundo se hubiera terminado y se tuviera que dedicar una velada para celebrarlo, según la costumbre de las sociedades literarias de provincia, que invitan a ilustres conferencistas para conmemorar las glorias locales lentamente resquebrajadas por el olvido, ninguno sería más adecuado que Borges para evocar delante de un público cauteloso, el mundo desaparecido, su variada superficie de quinientos diez millones de kilómetros cuadrados cubiertos el setenta por ciento por extensiones

26 de agua salitrosa, que los hombres -recordaría el persuasivo oradorgeneralmente llamaban mar, o en ciertos casos, con énfasis, océano. La obra de Borges, que no se cansa de enumerar los objetos cambiantes y las innumerables formas de la realidad, es un intento de apresar la fugaz multiplicidad de la vida, para conservarla en la concisa precisión de una voz de enciclopedia. Pero el mundo de la página de Borges, se sustrae a la acrobacia de las palabras que pretenden aferrarlo, estar siempre más allá, fuera de la página, así como cada realidad está siempre fuera de la sala de conferencias donde se la ilustra y se la exalta. Las palabras de Borges expresan la nostalgia por la vida que persiguen. En lírica evocación al abuelo, el Coronel Francisco Borges, celebrado en las memorias familiares y en la historia argentina, éste se aleja sobre su caballo, inaccesible al verso que quisiera penetrar su secreto; mientras que la poesía sobre el tigre con sus rimas y sus figuras retóricas solamente logra dibujar un tigre de papel que no alcanza al otro, el que se desliza en la selva más allá de cada verso. 
Borges, presumiblemente desearía que su obra fuera una arca de Noé, llena de vida arrancada a la destrucción y ordenada como las parejas de animales escogidas para representar y continuar la variedad de la naturaleza, intérprete y víctima de la ausencia moderna; sin embargo, debe resignarse con algo semejante al mapa del imperio que narra una parábola, que reproduce fielmente el territorio y lo adhiere con exactitud, pero que al final es hecho jirones por el viento. Los conjurados, que en un cuento quieren organizar un parlamento mundial que represente a todos los hombres y a la realidad entera acuerdan que el único parlamento del mundo sea el mundo mismo, en el impredecible fluir de las cosas fugaces que ningún símbolo o representante puede sustituir en su singularidad sin que pierdan su esencia.

Borges es el gran poeta de la melancolía del papel, consciente de la aridez inscrita en la vanagloria de las palabras; no es el escrito de la mentira y del artificio amado por los literatos italianos que de él han difundido un culto equivocado. Borges, que en un ensayo sobre la antigua poesía escandinava compadece aquellas sofisticadas acobracias verbales con las cuales él mismo es indulgente en algunas páginas tortuosamente banales, conoce esa poesía de la simplicidad elemental que supera al individuo para identificarse con la realidad de cada uno. Su página es grande cuando se detiene, comprimiendo lo esencial de una historia o de una vida en pocas líneas: sobre la luz de una tarde o sobre el caer lento y potente de la lluvia, sobre la aproximación del sueño, sobre la sombra tierna y profunda de la casa paterna, sobre la valentía y la fidelidad, o sobre el regocijo de la frescura del agua, como en la espléndida narración sobre la especulación de Averroes.

Borges, artista innovador que tácitamente se sitúa en el seno conservador de su tradición familiar y de la vieja civilización europea, antes que nada advierte en sí mismo el exilio del individuo de aquella épica proximidad con el ritmo de la existencia; la ambigüedad moderna que impide radicarse en la plenitud de la vida y obliga al escritor contemporáneo al extrañamiento y la falsificación. Él sabe que su obra no es la vida, sino apenas un catastro suyo que a su vez se inserta, mínimo e inquietante, en la vida misma, como sucede en la Biblioteca de Babel, que contiene su propio catálogo, el cual también registra los innumera- 


\section{Claudio Magris}

bles falsos catálogos, según la paradoja matemática de la clasificación más vasta de elementos, que a su vez contiene su propia clasificación. Cada narración de Borges es a la vez la de su país imaginario Tlön, una voz ficticia agregada arbitrariamente a la Enciclopedia Británica, que poco a poco insinúa la dimensión imaginaria de lo real que se desliza en la irrealidad. Consciente de la naturaleza cartográfica de su pasión y también con una excitada admiración por la violencia y la crueldad, Borges a veces busca superar la esencial anemia de la constitución vital. Una aridez espiritual parece haber agotado en él las linfas del deseo erótico, transfiriendo su intensidad a la abstracción de la memoria, que confiere a su página una insólita ascesis sexual. La sublimación es tan intensa que consume toda energía; el amor arde totalmente en la intimidad del sentimiento y del pensamiento, en el apasionado y minucioso archivo de la persona amada. El amante está tan ocupado en catalogar en la mente y en el corazón las notas dominantes de su Beatriz, o a celebrar en vano después de su muerte sus aniversarios, que no le quedan fuerzas para aproximarla y realmente amarla. Borges es el poeta del amor reprimido y callado, ajeno a lo físico y sólo capaz de transfiguración; sus melancolías y sus meticulosos protocolos del corazón conocen la perdición del enamoramiento en el tierno encanto y la sospechosa acritud de quien, al imaginarlo de lejos, desconoce la totalidad del amor.

La aversión de Borges a la procreación no es solamente la objeción del místico a la inútil multiplicación de las ilusorias apariencias individuales, es también un atisbo de la esterilidad que acecha en su obra. Su dioses -él lo ha dicho-no le han concedido la expresión que crea la vida, sino solamente la alusión que la roza, su poesía muestra la melancolía de este indicio fugitivo, "la inminencia de una revelación que no se produce", la espera desilusionada de un secreto que se desvanece un momento antes de ser dicho. Borges es el poeta del instante todavía no extendido en la duración, de la posibilidad no realizada: algunos de sus cuentos parecen un rapidísimo esbozo de una narración por escribir.

En esta potencialidad desilusionada, Borges encarna el destino de la literatura, a la que ya no le es permitido transmitir valores y narrar historias íntegras en su significado. Él evade esta crisis, fingiéndose crítico de libros inexistentes, camuflando paradójicamente su invención 


\section{LA NOVELA Y LA PROSA}

como nota bibliográfica o como glosa erudita, donde le es posbile ocultar, con el abuso evidente de la mistificación, la ausencia de la verdad. En ello consiste su modernidad y no en la ostentación de un laborioso bagaje cultural, demasiado admirado superficialmente.

Borges poeta grande de la precariedad humana, es un lector omnívoro, pero no es un escritor culto; su erudición es un sedimento de elementos más acumulados que asimilados, es el repertorio imitador del escritor colonial -observa Cesare Acutis-que se apropia de la tradición de origen hasta la hipérbole. Su arte es discreto y complejo, entregado a aspectos marginales y reticentes, que parece fácil y resulta sumamente peligroso de imitar, como señala Carmelo Samonà. Al igual que los de Kafka, también los émulos de Borges terminaron copiando miserablemente las fáciles normas geométricas de sus intrincados laberintos y la fascinación superficial de sus comentarios apócrifos, perdiendo la dolorosa e irónica ambivalencia de su poesía, que muestra los extravíos de la inteligencia de la trama elemental del mundo. Por cierto, también es verdad que Borges mismo a veces parece repetirse en algunas páginas y que en la transcipción de algunas de sus excesivas entrevistas, obviamente excéntricas, parece uno de sus plagiarios.

Borges vive de la renta de sí mismo y a veces a buen precio; autor de pocas altísimas páginas y de muchas cansadas repeticiones, sabe que esta multiplicación de sus palabras exiguas en muchos casos es un abuso, o la máscara de una secreta aridez, de un cansancio resignado al estereotipo. Con melancólica ironía advierte, como ha dicho en un reciente prefacio, que lo que escribe ahora, es oído y juzgado no por lo que vale, sino en base a la idea preconcebida que de él se tiene.

Lo que escribe ya no le pertenece sino que se lo apropia el otro Borges. Ese Borges que dialoga con coquetería y pasión con los grandes escritores del pasado no es uno de ellos, no tiene su estatura y su grandeza. Es un eco de ellos, una sombra suya, un comentador y glosador de la gran poesía, como los exegetas medievales eran anotadores, intérpretes y divulgadores de los libros sagrados. Es uno de nosotros que sabe que está lejos de aquella grandeza, de no tenerla. Pero él sabe que la grandeza es aquello que nosotros no somos, y dice con enorme sobrecogimiento esta ausencia y esta distancia, esta nostalgia. Quizá Borges 


\section{Claudio Magris}

considere su fama un bluff: ha dicho que quiere escribir - tal vez ya lo ha hecho- una refutación y una amputación de Borges. Sería un cierto juego, una mistificación literaria, pero esta broma -como muchas de sus mistificaciones ocultaría púdicamente también una verdad, sería un modo de ser realmente sincero fingiendo jugar a ser sincero.

No solamente aquello que escribe, sino también lo que él vive pertenece ahora al otro, a Borges. "Al otro, a Borges, le suceden las cosas", ha escrito en una parábola que es tal vez la más grande y la más poética página que haya sido escrita acerca de la relación entre vivir y escribir. La palabra absorbe la vida, transforma los pequeños amores y placeres de cada día en una hipérbole exhibicionista y vanidosa: "Me gustan los relojes de arena, los mapas, la tipografía del siglo XVIII, las ètimologías, el sabor del café y la prosa de Stevenson, el otro comparte esas preferencias, pero en un modo vanidoso que las convierte en atributos de un actor."

La vida obliga a ceder todo a la escritura, a cederle sobre todo aquel indefinible e indecible dejarse vivir que constituye el anónimo e indiferente secreto de nuestra existencia: pasear por las calles y mirar el arco de un zaguán, perderse en el color de una tarde, adormecerse. Esta vida indiferente e inalcanzable que existe más en el río de las cosas que en los sentimientos y en las propias palabras o en los propios libros, más en los libros escritos por otros o en el rasgueo de una guitarra. Escribir no salva la vida aunque sí permite que algún instante sobreviva en las palabras, porque la vida no puede reconocer y reencontrar en ellas la propia verdad inmediata, inexpresable y fugitiva.

Borges es un maestro en la evocación de esta extrañeza de la vida a cada expresión, de la distancia del escritor y sus palabras. Él se reencuentra más en los libros de los demás o en el sonido de una guitarra porque la música de aquellas palabras o de aquellos acordes es una alusión a esa revelación que no se produce, es el eco o la imagen de algo que él siente dentro de sí y que nunca podrá decir, mientras que sus libros son la expresión consumada y definida, y por ello insuficiente, de su pensamiento y voluntad y pertenecen al pasado. Cada libro que hemos escrito pertenece al pasado, cada libro que leemos y volvemos a leer, es el presente; cada libro que hemos escrito es un momento en cierto modo 


\section{LA NOVELA Y LA PROSA}

ausente, que sentimos inferior a nuestra verdad de entonces y extraña a la de hoy.

La revelación más grande es aquella que nos hace descubrir, cómo nosotros existimos afuera, en la realidad externa, en el agua que refleja nuestra imagen o en la mirada que la recoge o la retiene, en la memoria y los sentimientos de los demás, que nos conservan y salvan en su corazón.

Existimos en quien nos ama y nos hace vivir en sus pensamientos. Nuestra verdadera muerte, para Borges, no ocurre con la extinción física: Esta última, como dice en la poesía "Límites", nos gasta incesante en cada momento, tiene lugar en cada vez que, sin saberlo, abrimos por última vez un libro que no tocaremos nunca más, o recorremos una calle a la cual nos regresaremos. La verdadera muerte, como dice en la espléndida parábola "El testigo", sucede cuando se cierran los últimos ojos que han visto nuestro rostro, cuando se apaga el último pensamiento de alguien que nos recuerda, cuando se borran las huellas que hemos dejado de nosotros en el mundo; el último sajón de "El testigo" muere arrastrando en la nada de las últimas imágenes de los ritos paganos, los ídolos y los sacrificios perdidos de una época desaparecida. Cada hombre para Borges tiene el sentimiento -como Dante en Infierno I, 32- de haber recibido y perdido algo infinito e irrecuperable. Es la intuición de la propia identidad, de ese vacío indefinible e impersonal del cual estamos hechos. Dentro de Shakespeare no hay nadie, existe solamente un poco de frío, una vanidad irreal y anónima que le permite ser muchos hombres, vestir y desnudar el alma de César, de Macbeth, de Julieta. Y Shakesperare para Borges es el modelo de cada hombre, que, como Dios es muchos y ninguno, un sueño sin nombre, anónimo y plural. Como dice el epílogo de "Borges y yo", el autorretrato de un hombre se encima, entrelaza e identifica con el paisaje del mundo; los rasgos que trazan sus caracteres también dibujan los perfiles de reinos y provincias, de bahías y caballos, de la innumerable multiplicidad del mundo. Borges quiere ser el poeta de la totalidad, del suceder captado integralmente, más allá del bien y del mal. En nombre de esta aceptación de las cosas tal como son, Borges, que tiene toda la grandeza épica y también la dureza del terrateniente conservador, ligado a la posesión e insensible a las miserias humanas, ha dirigido famosas y tristes alabanzas a la violencia y a la 
Claudio Magris

injusticia, tal vez con la actitud autodestructiva del reaccionario que se ofende a sí mismo con tal de atacar al conformismo progresista. Su mundo es el de la inmutable repetición de la epopeya agraria, reflejado en la obsesión circular que domina su fantasía. Tal vez él no ha visto el Aleph, la simultánea revelación de la totalidad; genial e irónicamente consciente de la escisión entre el yo que vive y el yo que escribe, Borges inventa entonces la historia de un Borges más afortunado y vanidoso, que tal vez ha visto al Aleph o, como escribe Roberto Paoli, que tiene sus buenas razones para decir que lo ha visto.

De aquella totalidad permanecen aislados algunos fragmentos, la desnuda presencia de algunos hechos. Borges reduce la vida a la indiferencia de los hechos, los cuales obedecen a una inexorable ley física o a la casualidad, ambas ajenas al juicio moral. En el universo de Borges existen códigos de conducta, pero no existe la culpa ni aquel residuo suyo que es la psicología y sus cicatrices en el corazón del hombre sometido al examen de conciencia. Sobre estas grietas de la personalidad Borges edifica un orden objetivo, como el Valle de Adriano o el Puerto de Kipling, una ley en la cual el individuo se identifica con su propio destino. Por eso él desprecia la introspección de la novela psicológica y ama las férreas leyendas nórdicas, en las cuales lo esencial -la batalla, la venganza, la muerte-emerge con la elementaridad de los hechos puros, del mar que rompe contra las rocas o de los graznidos de una gaviota.

Estos hechos retornan a los ojos casi apagados del poeta, que también se percibe como otro de ellos, aislado en el mundo como un objeto abandonado en la playa. Hace dos años en Venecia nos pedía le describiéramos los colores y las formas de las cosas sobre el agua; cuando el discurso se refería a alguna obra suya, se retraía embarazado. Sabía que no tenía derecho de vanagloriarse de sus palabras. Cuando le agradecíamos esas primeras líneas de El Aleph que nos han hecho comprender a cada uno de nosotros qué cosa hemos perdido verdaderamente con la muerte de alguien querido, dudaba; tal vez se preguntaba incrédulo cómo había sucedido que en la imprevisible y suprapersonal gracia de la poesía, justamente él hubiera tropezado con aquella verdad y aquellas palabras que ahora formaban parte del mundo y no pertenecían más a él que a cualquier otro. Probablemente pensaba de sus libros aquello que 
Cisterión, el minotauro de su narración, piensa del sol y de las estrellas: "tal vez los he creado yo, pero no me acuerdo". Ahora Borges cumple ochenta años. Hemos aprendido de él, para siempre, que el tiempo como ha escrito, es un río que nos devora, pero nosotros somos ese río. $\mathrm{Ni}$ siquiera de esta verdad, quizá, sabremos hacer uso de manera que nos ayude. La vida, ha dicho Borges, nos da a cada uno todo, pero casi nadie lo sabe. 